\title{
FÓRUM
}

Fórum rovatunkban a Közjavak folyóirat korábbi számaiban megjelent tanulmányokhoz érkezett hozzászólásokat, vitaindítókat, reflexiókat, megjegyzéseket valamint a tudományos élet eseményei bemutató írásokat közöljük. A közös gondolkodás alapjainak továbbépítéséhez kíván fórumot biztosítani, továbbá a közjogi kutatások aktuális kérdéseinek megvitatásához, közvetlenül teret adva az aktuális témákkal kapcsolatos hírek megjelenésének, valamint a szakmai vélemények és különböző álláspontok közlésének a különböző jogágak közötti szabad és kötetlen kommunikáció jegyében.

\section{A BALATON, MINT JOGALANY BÜNTETHETŐ LENNE?*}

\section{Bordás Péter ${ }^{1}$}

Az elmúlt években egyre többet hallhatunk arról, hogy valamilyen természetes vizet jogalanyisággal ruháznak fel. Legutóbb 2017-ben váltott ki megosztó szakmai vitát, hogy az új-zélandi Északi-szigeten található Whanganui folyó önálló jogalanyiságot nyert. Úgy látszik, a hullám továbbterjed, s immáron Európában is több kezdeményezés született - legutóbb Hollandiában - mely valamely folyó vagy tó jogalanyisággal történő felruházását tüzte ki célul.

2017-ben hazánkban, a Föld napja alkalmából jelent meg egy felhívás az európai parlamenti képviselőköz címezve, melynek célja a legjelentősebb európai tavak és folyók alapvető jogainak elismerése volt minden európai országban, ezzel jogharmonizációt teremtve a kérdésben. Magyarországon először a Balaton esetében merült fel ennek a kérdése, mellyel a világon először ismerhetnék el egy tó, mint ökoszisztéma önálló jogalanyi státuszát (ha a holland jogalkotás meg nem elöz bennünket).

Ugyanakkor jogosan merül fel az a kérdés, hogy szükség van-e egyáltalán önálló jogalanyiságot biztosítani egy tónak vagy folyónak? E kérdésben a szakmai és tudományos szervezetek álláspontja eltérö.

A téma aktualitását észlelve az MTA Állam- és Jogtudományi Bizottság Közjogi Albizottsága és az Alapvető Jogok Biztosának Hivatalával közös szakmai mühelybeszélgetést szervezett 2018. április 24-én (kedden) 14.00

\footnotetext{
${ }^{*}$ DOI 10.21867/KjK/2018.2.9.

${ }^{1}$ Dr. Bordás Péter PhD, tudományos segédmunkatárs, MTA-DE Közszolgáltatási Kutatócsoport; Debreceni Egyetem, Állam- és Jogtudományi Kar.
} 
órától az ÁJBH Nádor utcai Dísztermében „A Balaton jogi meghatározásának új lehetőségei az új-zélandi Whanganui folyó jogalanyisága tükrében" címmel. A vizek jogalanyiságának kérdését több szempontból körbejáró mühelybeszélgetés célja új utak és eszközök keresése volt az ökológiai rendszerek müködését tiszteletben tartó természeti erőforrás-hasznosítás érdekében.

Horváth M. Tamás, az MTA AJB Közjogi Albizottságának elnöke nyitotta meg a kerekasztal-beszélgetést, majd nyolc a meghívóban szereplő szakmai előadás, hozzászólás következett.

Szilágyi János Ede (ME ÁJK) az új-zélandi eseményeket és annak sajátosságait ismertette röviden, így különösen azt is, hogy az adott esetben lényegében emberi jogi ügyről van szó, az őslakosok védelméről. Felhívta a figyelmet arra is, hogy a jogalanyiság önmagában nem jelent garanciát egy folyónak, például a szennyezés ellen. A Balaton esetében pedig annak a problémáját emelte ki többek között, hogy problémás lehet a tó határainak megalkotása.

Sulyok Katalin (LLM Harvard, AJBH) a témát nemzetközi jogi aspektusból ragadta meg, a természet elméleti megközelítésének aspektusait mutatta be, $\mathrm{s}$ rávilágított arra, hogy különbség van az emberi illetve a természetközpontú védelem között. A Whanganui folyóhoz kapcsolódóan azt a kérdést vetette fel, hogy az új szabályozás hogyan fog illeszkedni a common law jogrendszer kereti közé? A Balaton esetében pedig arra az első hallásra bizarr lehetőségre hívta fel a figyelmet, hogy ha jogalanyiságot kapna, akkor akár kártérítési jogát is gyakorolhatná.

Baranyai Gábor (NKE VTK FFTI) a víztest jogalanyiságának uniós értelmezése kapcsán jogosan tette fel azt a kérdés, hogy mire jó az egész jogalanyisággal való felruházás. Továbbá felhívta a figyelmet arra, hogy a jelenlegi jogi környezetben nehezen lenne értelmezhető egy tó jogalanyisága, ahogyan az új-zélandi esetben is nehézkes lesz. Különösen nehéz lenne egy folyó jogalanyiságának meghatározása Európán belül, ahol a vízgyüjtő területekkel együtt több országot is érinthetne a kérdés.

Újszászi Györgyi és Kardos Gábor (Védegylet és Balatoni Kör) arra világítottak rá, hogy a Balaton kapcsán számos környezetpolitikai probléma, van, s új jövőképre van szükség, a tó egyenletesebb terhelésére. Kiemelték, hogy a magyar jog mindig is innovatív volt, sokszor előzte meg a korát, miért ne tehetné most is ezt a Balaton jogalanyiságának elfogadásával. Mint mondták társadalmi elvárás, hogy a jog alkalmazkodjon a társadalmi változásokhoz.

Józsa János (MTA levelező tag, BME) arról beszélt, hogy nem ugyan az a Duda, Tisza vagy épp a Balaton, sebezhetőségük is eltérö, így a jogalanyiság szempontjából sem összehasonlíthatóak. A vizek védelme kapcsán Finnország példáját és gyakorlatát hozta fel, mely számunkra is követendö lenne. 
G. Tóth László (MTA ÖK BLI) a kezdeményezés természettudományi megközelítéséről beszélt, a vízről, mint közjószágról s kiemelte, hogy az új Balaton-törvény nem biztosít kellő garanciát. A jogalanyiság kérdésként tette fel, hogy ez együtt járna-e a Balaton büntethetőségével, azaz ha másnak kárt okoz a medréből való kilépéssel, vagy ha valaki belefullad - azaz tisztázni kell, milyen jogalanyiságról is van szó, $\mathrm{s}$ ki lenne a tulajdonos.

Pump Judit (AJBH) a jogalanyiságot célzó kezdeményezést az Alaptörvény P) cikkén keresztül értelmezte. A jogalanynak fizikai teste kell hogy legyen, melyhez a védett növények és állatok is hozzátartoznak - mondta. Feltette azt a kérdést, hogy a jogalanyisághoz szükséges-e az önazonosság, a Balaton vajon tudja-e hogy ki ö? Továbbá arra a problémára is reflektált, hogy ebben az esetben ki alkotná meg a jogszabályt, ki képviselhetné a Balatont?

Agócs Ilona (AJBH) arról beszélt, hogy a Balaton jogalanyiságát célzó kezdeményezés lehet-e a Balaton-törvény továbbfejlesztésének egyik alternatívája. Felhívta a figyelmet arra, hogy az új törvény alapján a helyi önkormányzatok szabadabb kezet kapnak a fejlesztések érdekében, mely nem feltétlenül vezet majd jó eredményre. Továbbá arról is beszélt, hogy a papír alapú térképek és a valóság között sokszor nagy a különbség - mely a tó fizikai testének meghatározását is nehezítené.

A témafelvetések utána a szakmai vitáé volt a föszerep, az elhangzottakhoz számos kérdés és reflexió érkezett. A rendezvénynek nem egy közös álláspont kidolgozása volt a célja, mint inkább az eltérő nézőpontok megvilágítása, s ennek érdekében közös publikációs lehetőségről döntöttek a résztvevők, mely segíti a szakmai- és társadalmi vitát. 